\title{
BRAND IDENTIFICATION, SATISFACTION, BRAND TRUST, DAN COMMITMENT TERHADAP CUSTOMER LOYALTY PADA KONSUMEN MOTOR SPORT
}

\author{
DENNY SEPTA HARYANTI \\ EDDY HERMAWAN \\ Trisakti School of Management, Jl. Kyai Tapa No. 20, Jakarta, Indonesia \\ Eddyhermawan88@gmail.com
}

\begin{abstract}
The purpose of this study was to examine and analyze the influence of customer brand identification (CBI), customer satisfaction (SAT), customer brand trust (CBT), and customer commitment (CM) to customer loyalty (CL) on Yamaha Vixion motor sport consumers in DKI Jakarta. The form of research conducted in this study are causal and descriptive. Sampling using pusposive sampling technique with the number of respondents as many as 281 respondents. The data analysis method used in this study is SEM (Structural Equation Model) with AMOS tools. The result of this study indicates that CBI, SAT, CBT, and CM had effect to CL. CBT had effect to CL mediating through SAT, CBT, and CM. Then, SAT had effect to CM mediating through CBT. CBI had effect to CBT mediating through SAT, and CBI had effect to CM mediating through SAT.
\end{abstract}

Keywords: Customer brand identification, customer satisfaction, customer brand trust, customer commitment, customer loyalty

Abstrak: Tujuan penelitan adalah untuk menguji dan menganalisa pengaruh customer brand identification (CBI), customer satisfaction (SAT), customer brand trust (CBT), dan customer commitment (CM) terhadap customer loyalty $(\mathrm{CL})$ pada konsumen motor sport Yamaha Vixion di DKI Jakarta. Bentuk penelitian yang dilakukan pada penelitian ini adalah kausal dan deskriptif. Pengambilan sampel menggunakan teknik purposive sampling dengan jumlah responden sebanyak 281 responden. Metode analisis data yang digunakan dalam penelitian ini adalah SEM (Structural Equation Modelling) dengan alat bantu AMOS. Hasil dari penelitian ini menunjukkan bahwa CBI, SAT, $C B T$, dan CM berpengaruh terhadap CL. CBI berpengaruh terhadap CL dimediasi oleh SAT, CBT, dan CL. Lalu, $S A T$ berpengaruh terhadap $C M$ dimediasi oleh $C B T$. CBI berpengaruh terhadap $C B T$ dimediasi oleh $S A T$, dan $C B I$ berpengaruh terhadap CM dimediasi oleh SAT.

Kata kunci: Customer brand identification, customer satisfaction, customer brand trust, customer commitment, customer loyalty

\section{PENDAHULUAN}

Yamaha memiliki penjualan sebanyak 1.434.217 dengan persentase 22,10\% pada tahun 2019 yang turun dari tahun sebelumnya dengan penjualan sebanyak 1.455 .088 dengan persentase $22.80 \%$ yang didapat dari AISI 2019 . Yamaha V-IXION pada tahun 2019 juga terkalahkan oleh pesaingnya, Honda CBR, padahal Yamaha V-IXION unggul di tahun 2017- 
2018 menurut topbrand. Oleh sebab itu, peneliti tertarik untuk melakukan penelitian terhadap penjualan produk motor Yamaha dikarenakan pernah mengalami penurunan penjualan di tahun 2019.

Yamaha Vixion tahun 2020 dengan semboyan live the legend sudah didesain lebih cepat dan bertenaga khusus bagi para pecinta motor sport di tanah air. Banyaknya perubahan yang dilakukan Yamaha demi mempertahankan konsumen yang ada, diharapkan dapat terus melakukan inovasi dan perubahan bagi produk motor sport Yamaha lainnya. Hal ini dapat meningkatkan terjadinya $\mathrm{CL}$ pada produk Yamaha. Dalam penelitian ini, penulis mengaitkan beberapa variabel yang digunakan beberapanya dari variabel $C B I, S A T, C B T, C M$, dan CL.

\section{Customer Brand Identification}

Menurut Lam (2013 235), identifikasi merek pelanggan merupakan kondisi psikologis dalam mempersepsikan, merasakan, dan menilai kepemilikannya terhadap suatu merek. Hughes dan Ahearne (2010) mengartikan sebagai sejauh mana seseorang mendefinisikan dirinya sendiri dengan atribut yang sama yang dia percaya dalam mendefinisikan merek. Badrinarayanan dan Laverie (2011) mengartikan sebagai peningkatan kecenderungan konsumen untuk sangat peduli tentang keberhasilan dan kegagalan merek dan terlibat dalam perilaku yang menguntungkan merek.

\section{Customer Satisfaction}

Menurut Taylor dan Baker (2014), kepuasan konsumen adalah pengaruh utama dalam pembentukan niat pembelian masa depan konsumen. Kotler dan Keller $(2015,33)$ mendefinisikan sebagai penilaian seseorang terhadap persepsi kinerja suatu produk dalam hubungannya dengan harapan. Lin (2015) mendefinisikan sebagai hasil emosional dan psikologis dari pengalaman pelanggan individu.

\section{Customer Brand Trust}

Menurut Pavlou (2017), kepercayaan merek konsumen merupakan kemauan konsumen untuk mengandalkan kemampuan merek untuk melakukan fungsi yang dinyatakannya. Kotler dan Keller $(2015,231)$ merupakan kesediaan perusahaan untuk bergantung pada mitra bisnis yang bergantung pada sejumlah faktor interpersonal dan antar organisasi, seperti kompetensi yang dirasakan perusahaan, integritas, kejujuran, dan kebajikan. Dai (2019) merupakan adalah komitmen perusahaan untuk menunjukkan kepribadiannya yang unik kepada konsumen, sehingga konsumen memahami bahwa nilainilai inti perusahaan adalah "berorientasi pelanggan, berorientasi layanan".

\section{Customer Commitment}

Menurut Alteren dan Tudoran (2016), komitment pelanggan merupakan perasaan yang kuat untuk menopang hubungan. Matikiti (2019) merupakan perasaan yang kuat untuk mempertahankan hubungan dengan penyedia layanan. Karjaluoto (2015) merupakan elemen hukum yang melakukan transaksi komersial, yang didasarkan pada kepercayaan antara para pihak.

\section{Customer Loyalty}

Menurut Homburg (2017), loyalitas pelanggan adalah niat pelanggan untuk terlibat lagi dalam perjalanan titik kontak yang disediakan oleh pengecer tertentu. Anderson dan Srinivasan (2003) mengungkapkan sikap positif pelanggan terhadap perusahaan atau merek yang menghasilkan perilaku pembelian kembali yang berulang dan sensitivitas pelanggan yang lebih rendah terhadap harga dan penawaran pesaing. Kotler dan Keller $(2015$, 153) merupakan komitmen yang dipegang teguh untuk membeli kembali atau melindungi produk atau layanan yang disukai di masa depan terlepas dari pengaruh situasional 
dan upaya pemasaran yang berpotensi menyebabkan peralihan Perilaku.

\section{METODE PENELITIAN}

Pengumpulan data dalam penelitian ini menggunakan kuesioner sebagai alat pengumpul data primer. Responden dalam penelitian ini adalah konsumen motor sport Yamaha Vixion dengan kriteria berikut Responden memiliki SIM C, memiliki penghasilan, telah bergabung dalam komunitas motor Yamaha, mempunyai motor Yamaha Vixion, merupakan pengambil keputusan atas kepemilikan, pembelian, dan penggunaan motor Yamaha Vixion, telah menggunakan motor Yamaha Vixion minimal dalam enam bulan terakhir.

CBI merupakan pusat pemahaman konsumen dalam menilai apakah produk Yamaha Vixion mampu diidentifikasi dan dikenali konsumen dengan baik atau tidak. SAT merupakan suatu tingkatan dimana kebutuhan, keinginan dan harapan dari konsumen motor
Yamaha dapat terpenuhi yang akan mengakibatkan terjadinya pembelian kembali motor Yamaha di masa depan. CBT merupakan perasaan aman konsumen dalam penggunaan motor sport Yamaha Vixion, yang didasarkan pada persepsi bahwa produk tersebut reliable dan responsible terhadap minat dan keselamatan konsumen. CM merupakan keterikatan antara konsumen dengan motor Yamaha sebagai penyedia produk yang berlangsung secara berkelanjutan atau hubungan yang tetap. $C L$ merupakan komitmen yang dipegang kuat oleh konsumen motor Yamaha untuk membeli kembali motor sport Yamaha Vixion di masa depan meskipun ada pengaruh situasi dan usaha pemasaran motor lain yang berpotensi menyebabkan peralihan perilaku.

Adapun skala yang digunakan dalam penelitian adalah skala likert. Adapun skala varibel dan pengukuran dari penelitian ini dinyatakan beserta indikatornya dalam bentuk tabel seperti berikut ini:

Tabel 1 Pengukuran Variabel

\begin{tabular}{|c|c|c|c|}
\hline No & Variabel & Indikator & $\begin{array}{c}\text { Skala } \\
\text { Pengukuran }\end{array}$ \\
\hline 1. & CBI & $\begin{array}{l}\text { 1. Saya merasa cocok dengan motor Yamaha Vixion. } \\
\text { 2. Saya merasa motor Yamaha Vixion memiliki desain } \\
\text { yang elegan. } \\
\text { 3. Saya mengetahui produk yang dijual oleh Yamaha. } \\
\text { 4. Secara keseluruhan, saya merasa produk yang } \\
\text { dijual oleh motor Yamaha sesuai dengan apa yang } \\
\text { saya inginkan. }\end{array}$ & Likert \\
\hline 2. & SAT & $\begin{array}{l}\text { 1. Saya merasa puas terhadap produk yang } \\
\text { ditawarkan Yamaha. } \\
\text { 2. Saya merasa senang terhadap pengalaman saya } \\
\text { selama menggunakan Yamaha Vixion. } \\
\text { 3. Saya merasa produk yang diberikan Yamaha } \\
\text { memberikan pengalaman berkendara yang tak } \\
\text { terlupakan. } \\
\text { 4. Saya merasa yakin bahwa Yamaha merupakan } \\
\text { perusahaan yang juga bagus untuk berbisnis. }\end{array}$ & Likert \\
\hline
\end{tabular}




\begin{tabular}{ll}
\hline 1. & $\begin{array}{l}\text { Saya memiliki rasa kepercayaan terhadap motor } \\
\text { Yamaha Vixion. }\end{array}$ \\
3. & Saya percaya bahwa motor Yamaha Vixion aman \\
bagi saya. & SBT \\
3. Saya percaya bahwa Yamaha tidak melakukan \\
penipuan terhadap saya. \\
4. Saya merasa bahwa Yamaha mampu menanggapi \\
masalah dengan cepat dan tepat.
\end{tabular}

Data yang digunakan dalam penelitian ini adalah data primer dan data sekunder. Metode analisis data yang digunakan dalam penelitian ini adalah metode SEM CFA. Seluruh data yang diperoleh dari responden melalui kuesioner akan diolah menggunakan AMOS (Analysis Moment of Stuctural) 24.

HASIL

Tabel 2 Hasil Uji Goodness of Fit

\begin{tabular}{|lccc|}
\hline $\begin{array}{c}\text { Kriteria Goodness } \\
\text { of Fit }\end{array}$ & Hasil & Acuan & Kriteria \\
\hline Chi Squares & 305.979 & Diharapkan Kecil & Good fit \\
CMIN/DF & 1.538 & Dibawah 2.00 & Good fit \\
GFI & 0.906 & Baik Mendekati 1 & Good fit \\
AGFI & 0.880 & Diatas 0.90 & Marginal fit \\
RMSEA & 0.044 & Dibawah atau sama dengan & Good fit \\
& & 0.08 & \\
TLI & 0.981 & Diatas 0.90 & Good fit \\
\hline
\end{tabular}




\begin{tabular}{|llll|}
\hline NFI & 0.956 & Diatas 0.90 & Good fit \\
CFI & 0.984 & Diatas 0.90 & Good fit \\
\hline
\end{tabular}

Berdasarkan tabel di atas, dijelaskan model dapat digunakan. Dimana seluruh ketentuan goodness of fit model penelitian ini telah memiliki nilai di atas rata-rata (acuan) kecuali AGFI yang berada dekat dengan batas sebesar .880 .

Tabel 3 Discriminant Validity

\begin{tabular}{|c|c|c|c|c|c|}
\hline & $\mathrm{CBI}$ & SAT & CBT & $\mathrm{CM}$ & $\mathrm{CL}$ \\
\hline CBI1 & .925 & .429 & .355 & .458 & .563 \\
\hline $\mathrm{CB} / 2$ & .922 & .427 & .354 & .457 & .561 \\
\hline $\mathrm{CB} 13$ & .918 & .426 & .352 & .455 & .559 \\
\hline CBI4 & .924 & .428 & .355 & .458 & .562 \\
\hline SAT1 & .416 & .898 & .441 & .483 & .653 \\
\hline SAT2 & .434 & .936 & .460 & .503 & .681 \\
\hline SAT3 & .420 & .906 & .446 & .487 & .659 \\
\hline SAT4 & .409 & .882 & .434 & .474 & .641 \\
\hline CBT1 & .351 & .450 & .914 & .553 & .680 \\
\hline CBT2 & .346 & .443 & .902 & .545 & .671 \\
\hline CBT3 & .352 & .451 & .917 & .554 & .682 \\
\hline CBT4 & .304 & .390 & .793 & .480 & .590 \\
\hline CM1 & .435 & .472 & .531 & .879 & .679 \\
\hline CM2 & .452 & .491 & .552 & .913 & .706 \\
\hline CM3 & .444 & .482 & .542 & .897 & .693 \\
\hline CM4 & .437 & .474 & .533 & .882 & .682 \\
\hline CL1 & .542 & .648 & .663 & .689 & .892 \\
\hline CL2 & .543 & .649 & .664 & .690 & .893 \\
\hline CL3 & .529 & .633 & .647 & .673 & .870 \\
\hline
\end{tabular}




\begin{tabular}{rccccc}
\hline CL4 & .534 & .638 & .653 & .678 & .878 \\
CL5 & .498 & .595 & .608 & .632 & .818 \\
CL6 & .534 & .638 & .653 & .679 & .878 \\
\hline
\end{tabular}

Dari tabel diatas dapat dlihat bahwa masing-masing indikator konstruknya lebih besar daripada kolerasi indikator konstruk lainnya. Seperti yang dikutip Ghozali $(2017,145)$ bahwa konstruk laten memprediksi ukuran pada blok mereka lebih baik daripada ukuran pada blok lainnya.

Tabel 4 Convergent Validity

\begin{tabular}{|c|c|c|c|c|}
\hline Variabel & Indikator & Loading Factor & Cut Off & Keterangan \\
\hline \multirow{4}{*}{$\mathrm{CBI}$} & $\mathrm{CBI} 1$ & 925 & .5 & Valid \\
\hline & CBI2 & $\begin{array}{l}.920 \\
.922\end{array}$ & .5 & Valid \\
\hline & $\mathrm{CBI3}$ & .918 & .5 & Valid \\
\hline & $\mathrm{CBI} 4$ & .924 & .5 & Valid \\
\hline \multirow{4}{*}{ SAT } & SAT1 & .898 & .5 & Valid \\
\hline & SAT2 & .936 & .5 & Valid \\
\hline & SAT3 & .906 & .5 & Valid \\
\hline & SAT4 & .882 & .5 & Valid \\
\hline \multirow{5}{*}{ CBT } & & & .5 & Valid \\
\hline & CBT1 & .914 & .5 & Valid \\
\hline & CBT2 & .902 & & \\
\hline & CBT3 & .917 & .5 & Valid \\
\hline & CBT4 & .793 & .5 & Valid \\
\hline \multirow{5}{*}{$\mathrm{CM}$} & & & .5 & Valid \\
\hline & CM1 & .879 & .5 & Valid \\
\hline & $\mathrm{CM} 2$ & .913 & & \\
\hline & $\mathrm{CM} 3$ & .897 & .5 & Valid \\
\hline & CM4 & .882 & .5 & Valid \\
\hline \multirow{6}{*}{$C L$} & & .892 & .5 & Valid \\
\hline & CL1 & .893 & .5 & Valid \\
\hline & CL2 & .870 & .5 & Valid \\
\hline & CL4 & .878 & .5 & Valid \\
\hline & CL5 & .818 & .5 & Valid \\
\hline & CL6 & .878 & .5 & Valid \\
\hline
\end{tabular}

Berdasarkan tabel diatas dapat diketahui bahwa semua indikator dinyatakan valid. Hal ini ditunjukkan dengan nilai factor loading yang didapatkan masing-masing indikator lebih dari .50 (Ghozali 2017, 141). 
Tabel 5 Uji Reliabilitas

\begin{tabular}{|c|c|c|c|c|c|c|}
\hline Variabel & Indikator & $\begin{array}{l}\text { Standardized } \\
\text { Factor } \\
\text { Loading }\end{array}$ & $\begin{array}{c}\text { SFL } \\
\text { Kuadrat } \\
\text { (Persepsi) }\end{array}$ & $\begin{array}{l}\text { Error } \\
{[\varepsilon j]}\end{array}$ & $\begin{array}{l}\text { Construct } \\
\text { Reliability }\end{array}$ & $\begin{array}{l}\text { Variance } \\
\text { Extrated }\end{array}$ \\
\hline \multirow{5}{*}{$\mathrm{CBI}$} & $\mathrm{CB} \mid 1$ & .925 & .856 & .144 & \multirow{5}{*}{.958} & \multirow{5}{*}{.851} \\
\hline & $\mathrm{CBI} 2$ & .922 & .850 & .150 & & \\
\hline & $\mathrm{CBI} 3$ & .918 & .843 & .157 & & \\
\hline & $\mathrm{CB} \mid 4$ & .924 & .854 & .146 & & \\
\hline & Total & 3,689 & 3,403 & .597 & & \\
\hline \multirow{4}{*}{ SAT } & SAT1 & .898 & .806 & .194 & \multirow{5}{*}{.948} & \multirow{5}{*}{.821} \\
\hline & SAT2 & .936 & .876 & .124 & & \\
\hline & SAT3 & .906 & .821 & .179 & & \\
\hline & SAT4 & .882 & .780 & .220 & & \\
\hline \multirow{6}{*}{ CBT } & Total & 3,622 & 3,283 & .717 & & \\
\hline & CBT1 & .914 & .835 & .165 & \multirow{5}{*}{.934} & \multirow{5}{*}{.800} \\
\hline & CBT2 & .902 & .814 & .186 & & \\
\hline & CBT3 & .917 & .841 & .159 & & \\
\hline & CBT4 & .793 & .629 & .371 & & \\
\hline & Total & 3,526 & 3,119 & .881 & & \\
\hline \multirow{4}{*}{$\mathrm{CM}$} & CM1 & .879 & .773 & .227 & \multirow{4}{*}{.940} & \multirow{4}{*}{.798} \\
\hline & $\mathrm{CM} 2$ & .913 & .834 & .166 & & \\
\hline & CM3 & .897 & .805 & .195 & & \\
\hline & CM4 & .882 & .780 & .220 & & \\
\hline \multirow{8}{*}{$\mathrm{CL}$} & Total & 3,571 & 3,192 & .808 & \multirow{8}{*}{.950} & \multirow{8}{*}{.760} \\
\hline & CL1 & .892 & .796 & .204 & & \\
\hline & CL2 & .893 & .797 & .203 & & \\
\hline & CL3 & .870 & .757 & .243 & & \\
\hline & CL4 & .878 & .771 & .229 & & \\
\hline & CL5 & .818 & .669 & .331 & & \\
\hline & CL6 & .878 & .771 & .229 & & \\
\hline & Total & 5,229 & 4,561 & 1,439 & & \\
\hline \multicolumn{5}{|c|}{ Batas Yang Dapat Diterima } & $\geq .7$ & $\geq .5$ \\
\hline
\end{tabular}

Berdasarkan tabel diatas, hasil pengujian reliabilitas instrumen dengan construct reliability dan variance extracted menunjukkan instrumen sudah reliabel, yang ditunjukkan dengan nilai dari construct reliability dan variance extracted sudah memenuhi batas 
yang dapat diterima. Dengan demikian, semua indikator pada setiap variabel telah reliabel.

Pada uji hipotesis 1 dapat diketahui bahwa pengaruh $\mathrm{CBI}(\mathrm{CBI})$ terhadap $\mathrm{CL}(\mathrm{CL})$ adalah signifikan. Dimana dapat dilihat bahwa nilai $p$-value sebesar $0.000<0.05$, maka dikatakan memiliki pengaruh yang signifikan. Sedangkan nilai estimate sebesar .141 menandakan bahwa pengaruh $\mathrm{CBI}$ (CBI) terhadap $C L(C L)$ adalah positif. Kesimpulan dari pengujian hipotesis ini adalah $\mathrm{Ho}_{1}$ ditolak dan $\mathrm{Ha}_{1}$ diterima. Dengan kata lain bahwa terdapat pengaruh $\mathrm{CBI}(\mathrm{CBI})$ terhadap $\mathrm{CL}(\mathrm{CL})$ pada konsumen motor sport Yamaha Vixion di DKI Jakarta.

Pada uji hipotesis 2 dapat diketahui bahwa pengaruh $\mathrm{CBI}(\mathrm{CBI})$ terhadap SAT (SAT) adalah signifikan. Dimana dapat dilihat bahwa nilai $p$-value sebesar $0.000<0.05$, maka dikatakan memiliki pengaruh yang signifikan. Sedangkan nilai estimate sebesar .458 menandakan bahwa pengaruh $\mathrm{CBI}$ (CBI) terhadap SAT (SAT) adalah positif. Kesimpulan dari pengujian hipotesis ini adalah $\mathrm{Ho}_{2}$ ditolak dan $\mathrm{Ha}_{2}$ diterima. Dengan kata lain bahwa terdapat pengaruh $\mathrm{CBI}(\mathrm{CBI})$ terhadap $S A T$ (SAT) pada konsumen motor sport Yamaha Vixion di DKI Jakarta.

Pada uji hipotesis 3 dapat diketahui bahwa pengaruh $\mathrm{CBI}(\mathrm{CBI})$ terhadap $C B T(\mathrm{CBT})$ adalah signifikan. Dimana dapat dilihat bahwa nilai $p$-value sebesar $0.002<0.05$, maka dikatakan memiliki pengaruh yang signifikan. Sedangkan nilai estimate sebesar .175 menandakan bahwa pengaruh $\mathrm{CBI}$ (CBI) terhadap CBT (CBT) adalah positif. Kesimpulan dari pengujian hipotesis ini adalah $\mathrm{Ho}_{3}$ ditolak dan $\mathrm{Ha}_{3}$ diterima. Dengan kata lain bahwa terdapat pengaruh $\mathrm{CBI}(\mathrm{CBI})$ terhadap $\mathrm{CBT}$ (CBT) pada konsumen motor sport Yamaha Vixion di DKI Jakarta.

Pada uji hipotesis 4 dapat diketahui bahwa pengaruh $\mathrm{CBI}(\mathrm{CBI})$ terhadap $\mathrm{CM}(\mathrm{CM})$ adalah signifikan. Dimana dapat dilihat bahwa nilai $p$-value sebesar $0.000<0.05$, maka dikatakan memiliki pengaruh yang signifikan. Sedangkan nilai estimate sebesar .199 menandakan bahwa pengaruh $\mathrm{CBI}$ (CBI) terhadap CM (CM) adalah positif. Kesimpulan dari pengujian hipotesis ini adalah $\mathrm{Ho}_{4}$ ditolak dan $\mathrm{Ha}_{4}$ diterima. Dengan kata lain bahwa terdapat pengaruh $\mathrm{CBI}(\mathrm{CBI})$ terhadap $\mathrm{CM}(\mathrm{CM})$ pada konsumen motor sport Yamaha Vixion di DKI Jakarta.

Pada uji hipotesis 5 dapat diketahui bahwa pengaruh SAT (SAT) terhadap CL (CL) adalah signifikan. Dimana dapat dilihat bahwa nilai $p$-value sebesar $0.000<0.05$, maka dikatakan memiliki pengaruh yang signifikan. Sedangkan nilai estimate sebesar .245 menandakan bahwa pengaruh SAT (SAT) terhadap $C L(C L)$ adalah positif. Kesimpulan dari pengujian hipotesis ini adalah $\mathrm{H}_{5}$ ditolak dan $\mathrm{Ha}_{5}$ diterima. Dengan kata lain bahwa terdapat pengaruh SAT (SAT) terhadap CL (CL) pada konsumen motor sport Yamaha Vixion di DKI Jakarta.

Pada uji hipotesis 6 dapat diketahui bahwa pengaruh SAT (SAT) terhadap CM (CM) adalah signifikan. Dimana dapat dilihat bahwa nilai $p$-value sebesar $0.000<0.05$, maka dikatakan memiliki pengaruh yang signifikan. Sedangkan nilai estimate sebesar .200 menandakan bahwa pengaruh SAT (SAT) terhadap CM (CM) adalah positif. Kesimpulan dari pengujian hipotesis ini adalah $\mathrm{Ho}_{6}$ ditolak dan $\mathrm{Ha}_{6}$ diterima. Dengan kata lain bahwa terdapat pengaruh SAT (SAT) terhadap CM (CM) pada konsumen motor sport Yamaha Vixion di DKI Jakarta.

Pada uji hipotesis 7 dapat diketahui bahwa pengaruh SAT (SAT) terhadap CBT (CBT) adalah signifikan. Dimana dapat dilihat bahwa nilai $p$-value sebesar $0.000<0.05$, maka dikatakan memiliki pengaruh yang signifikan. Sedangkan nilai estimate sebesar .357 menandakan bahwa pengaruh SAT (SAT) terhadap CBT (CBT) adalah positif. Kesimpulan dari pengujian hipotesis ini adalah $\mathrm{Ho}_{7}$ ditolak dan $\mathrm{Ha}_{7}$ diterima. Dengan kata lain bahwa 
terdapat pengaruh SAT (SAT) terhadap CBT (CBT) pada konsumen motor sport Yamaha Vixion di DKI Jakarta.

Pada uji hipotesis 8 dapat diketahui bahwa pengaruh $C B T$ (CBT) terhadap $C L(C L)$ adalah signifikan. Dimana dapat dilihat bahwa nilai $p$-value sebesar $0.000<0.05$, maka dikatakan memiliki pengaruh yang signifikan. Sedangkan nilai estimate sebesar .293 menandakan bahwa pengaruh CBT (CBT) terhadap $C L(C L)$ adalah positif. Kesimpulan dari pengujian hipotesis ini adalah $\mathrm{H}_{8}$ ditolak dan $\mathrm{Ha}_{8}$ diterima. Dengan kata lain bahwa terdapat pengaruh CBT (CBT) terhadap CL (CL) pada konsumen motor sport Yamaha Vixion di DKI Jakarta.

Pada uji hipotesis 9 dapat diketahui bahwa pengaruh CBT (CBT) terhadap CM (CM) adalah signifikan. Dimana dapat dilihat bahwa nilai $p$-value sebesar $0.000<0.05$, maka dikatakan memiliki pengaruh yang signifikan. Sedangkan nilai estimate sebesar .386 menandakan bahwa pengaruh CBT (CBT) terhadap CM (CM) adalah positif. Kesimpulan dari pengujian hipotesis ini adalah $\mathrm{Hog}_{9}$ ditolak dan $\mathrm{Ha}_{9}$ diterima. Dengan kata lain bahwa terdapat pengaruh CBT (CBT) terhadap CM (CM) pada konsumen motor sport Yamaha Vixion di DKI Jakarta.

Pada uji hipotesis 10 dapat diketahui bahwa pengaruh $C M(C M)$ terhadap $C L(C L)$ adalah signifikan. Dimana dapat dilihat bahwa nilai $p$-value sebesar $0.000<0.05$, maka dikatakan memiliki pengaruh yang signifikan. Sedangkan nilai estimate sebesar .291 menandakan bahwa pengaruh CM (CM) terhadap $C L(C L)$ adalah positif. Kesimpulan dari pengujian hipotesis ini adalah $\mathrm{Ho}_{10}$ ditolak dan $\mathrm{Ha}_{10}$ diterima. Dengan kata lain bahwa terdapat pengaruh $C M(C M)$ terhadap $C L(C L)$ pada konsumen motor sport Yamaha Vixion di DKI Jakarta.

Pada uji hipotesis 11 dapat diketahui bahwa pengaruh $C B I$ terhadap $C L$ melalui $C M$ adalah signifikan. Dimana dapat dilihat bahwa nilai z hitung sebesar 3,592 > 1,96 maka dikatakan memiliki pengaruh yang signifikan. Sedangkan nilai estimate sebesar .058 (diperoleh dari .199*.291) menandakan bahwa pengaruh $C B I$ terhadap $C L$ melalui $C M$ adalah positif. Kesimpulan dari pengujian hipotesis ini adalah $\mathrm{H}_{11}$ ditolak dan $\mathrm{Ha}_{11}$ diterima. Dengan kata lain bahwa terdapat pengaruh $C B$ I terhadap $C L$ melalui $C M$ pada konsumen motor sport Yamaha Vixion di DKI Jakarta.

Pada uji hipotesis 12 dapat diketahui bahwa pengaruh $C B I$ terhadap CL melalui $S A T$ adalah signifikan. Dimana dapat dilihat bahwa nilai $\mathrm{z}$ hitung sebesar $5,413>1,96$ maka dikatakan memiliki pengaruh yang signifikan. Sedangkan nilai estimate sebesar .112 (diperoleh dari .458*.245) menandakan bahwa pengaruh $C B I$ terhadap $C L$ melalui $S A T$ adalah positif. Kesimpulan dari pengujian hipotesis ini adalah $\mathrm{Ho}_{12}$ ditolak dan $\mathrm{Ha}_{12}$ diterima. Dengan kata lain bahwa terdapat pengaruh $C B /$ terhadap CL melalui SAT pada konsumen motor sport Yamaha Vixion di DKI Jakarta

Pada uji hipotesis 13 dapat diketahui bahwa pengaruh $C B$ I terhadap $C L$ melalui $C B T$ adalah signifikan. Dimana dapat dilihat bahwa nilai $z$ hitung sebesar 2,865 > 1,96 maka dikatakan memiliki pengaruh yang signifikan. Sedangkan nilai estimate sebesar .051 (diperoleh dari .175*.293) menandakan bahwa pengaruh $C B I$ terhadap CL melalui $C B T$ adalah positif. Kesimpulan dari pengujian hipotesis ini adalah $\mathrm{Ho}_{13}$ ditolak dan $\mathrm{Ha}_{13}$ diterima. Dengan kata lain bahwa terdapat pengaruh $C B$ I terhadap $C L$ melalui $C B T$ pada konsumen motor sport Yamaha Vixion di DKI Jakarta.

Pada uji hipotesis 14 dapat diketahui bahwa pengaruh SAT terhadap CM melalui CBT adalah signifikan. Dimana dapat dilihat bahwa nilai z hitung sebesar 4,414>1,96 maka dikatakan memiliki pengaruh yang signifikan. Sedangkan nilai estimate sebesar .138 (diperoleh dari .357*.386) menandakan bahwa pengaruh SAT terhadap CM melalui CBT adalah positif. Kesimpulan dari pengujian hipotesis ini 
adalah $\mathrm{Ho}_{14}$ ditolak dan $\mathrm{Ha}_{14}$ diterima. Dengan kata lain bahwa terdapat pengaruh SAT terhadap CM melalui CBT pada konsumen motor sport Yamaha Vixion di DKI Jakarta.

Pada uji hipotesis 15 dapat diketahui bahwa pengaruh $C B /$ terhadap $C B T$ melalui $S A T$ adalah signifikan. Dimana dapat dilihat bahwa nilai $z$ hitung sebesar $4,780>1,96$ maka dikatakan memiliki pengaruh yang signifikan. Sedangkan nilai estimate sebesar .164 (diperoleh dari .458*.357) menandakan pengaruh $C B$ I terhadap CBT melalui SAT adalah positif. Kesimpulan dari pengujian hipotesis ini adalah $\mathrm{H}_{15}$ ditolak dan $\mathrm{Ha}_{15}$ diterima. Dengan kata lain bahwa terdapat pengaruh $C B /$ terhadap CBT melalui SAT pada konsumen motor sport Yamaha Vixion di DKI Jakarta.

Pada uji hipotesis 16 dapat diketahui bahwa pengaruh $C B I$ terhadap $C M$ melalui $S A T$ adalah signifikan. Dimana dapat dilihat bahwa nilai $z$ hitung sebesar $3,490>1,96$ maka dikatakan memiliki pengaruh yang signifikan. Sedangkan nilai estimate sebesar .092 (diperoleh dari .458*.200) menandakan bahwa pengaruh $C B I$ terhadap $C M$ melalui $S A T$ adalah positif. Kesimpulan dari pengujian hipotesis ini adalah $\mathrm{Ho}_{16}$ ditolak dan $\mathrm{Ha}_{16}$ diterima. Dengan kata lain bahwa terdapat pengaruh $C B /$ terhadap CM melalui SAT pada konsumen motor sport Yamaha Vixion di DKI Jakarta.

\section{PENUTUP}

Hipotesis pertama, terdapat pengaruh CBI terhadap CL pada konsumen motor sport Yamaha Vixion di DKI Jakarta. Hasil penelitian ini sesuai dengan penelitian "Exploring and validating social identification and social exchange-based drivers of hospitality CL". Hipotesis kedua, terdapat pengaruh $C B I$ terhadap SAT pada konsumen motor sport Yamaha Vixion di DKI Jakarta. Hasil penelitian ini sesuai dengan penelitian "Exploring and validating social identification and social exchange-based drivers of hospitality CL". Hipotesis ketiga, terdapat pengaruh $C B I$ terhadap CBT pada konsumen motor sport Yamaha Vixion di DKI Jakarta. Hasil penelitian ini sesuai dengan penelitian "Exploring and validating social identification and social exchange-based drivers of hospitality CL". Hipotesis keempat, terdapat pengaruh $C B I$ terhadap $C M$ pada konsumen motor sport Yamaha Vixion di DKI Jakarta. Hasil penelitian ini sesuai dengan penelitian "Exploring and validating social identification and social exchange-based drivers of hospitality CL". Hipotesis kelima, terdapat pengaruh SAT terhadap CL pada konsumen motor sport Yamaha Vixion di DKI Jakarta. Hasil penelitian ini sesuai dengan penelitian "Exploring and validating social identification and social exchange-based drivers of hospitality CL". Hipotesis keenam, terdapat pengaruh SAT terhadap CM pada konsumen motor sport Yamaha Vixion di DKI Jakarta. Hasil penelitian ini sesuai dengan penelitian "Exploring and validating social identification and social exchange-based drivers of hospitality CL". Hipotesis ketujuh, terdapat pengaruh SAT terhadap CBT pada konsumen motor sport Yamaha Vixion di DKI Jakarta. Hasil penelitian ini sesuai dengan penelitian "Exploring and validating social identification and social exchange-based drivers of hospitality CL". Hipotesis kedelapan, terdapat pengaruh CBT terhadap CL pada konsumen motor sport Yamaha Vixion di DKI Jakarta. Hasil penelitian ini sesuai dengan penelitian "Exploring and validating social identification and social exchange-based drivers of hospitality CL". Hipotesis kesembilan, terdapat pengaruh $C B T$ terhadap $C M$ pada konsumen motor sport Yamaha Vixion di DKI Jakarta. Hasil penelitian ini sesuai dengan penelitian "Exploring and validating social identification and social exchange-based drivers of hospitality CL". Hipotesis ke-1. terdapat pengaruh CM terhadap CL pada konsumen motor sport Yamaha Vixion di DKI Jakarta. Hasil penelitian ini sesuai dengan penelitian "Exploring and validating social 
identification and social exchange-based drivers of hospitality CL". Hipotesis ke-11, terdapat pengaruh $C B I$ terhadap $C L$ melalui $C M$ pada konsumen motor sport Yamaha Vixion di DKI Jakarta. Hasil penelitian ini sesuai dengan penelitian "Exploring and validating social identification and social exchange-based drivers of hospitality CL". Hipotesis ke-12, terdapat pengaruh $C B I$ terhadap $C L$ melalui $S A T$ pada konsumen motor sport Yamaha Vixion di DKI Jakarta. Hasil penelitian ini sesuai dengan penelitian "Exploring and validating social identification and social exchange-based drivers of hospitality CL". Hipotesis ke-13, terdapat pengaruh $C B I$ terhadap $C L$ melalui $C B T$ pada konsumen motor sport Yamaha Vixion di DKI Jakarta. Hasil penelitian ini sesuai dengan penelitian "Exploring and validating social identification and social exchange-based drivers of hospitality CL". Hipotesis ke-14, terdapat pengaruh SAT terhadap CM melalui CBT pada konsumen motor sport Yamaha Vixion di DKI Jakarta. Hasil penelitian ini sesuai dengan penelitian "Exploring and validating social identification and social exchange-based drivers of hospitality CL". Hipotesis ke-15, terdapat pengaruh $C B I$ terhadap $C B T$ melalui $S A T$ pada konsumen motor sport Yamaha Vixion di DKI Jakarta. Hasil penelitian ini sesuai dengan penelitian "Exploring and validating social identification and social exchange-based drivers of hospitality CL". Hipotesis ke-16, terdapat pengaruh $C B I$ terhadap $C M$ melalui SAT pada konsumen motor sport Yamaha Vixion di DKI Jakarta. Hasil penelitian ini sesuai dengan penelitian "Exploring and validating social identification and social exchange-based drivers of hospitality CL".

Beberapa keterbatasan yang penulis peroleh selama proses penyusunan skripsi adalah (1) Hanya menilai salah satu perusahaan yaitu Yamaha yang ada di Indonesia, (2) Sampel yang digunakan hanya didapat dari satu komunitas pengguna Yamaha Vixion di DKI Jakarta. Rekomendasi untuk penelitian selanjutnya (1) Penelitian selanjutnya sebaiknya meneliti perusahaan otomotif lainnya ataupun produk secara utuh, tidak hanya Yamaha, (2) Penggunaan faktor atau variabel hingga dapat membangun $C L$. Mengambil sampel yang lebih besar dari populasi yang sudah ada sebelumnya.

\section{REFERENCES:}

Alteren, G., \& Tudoran, A. A. 2016. Enhancing export performance: Betting on customer orientation, behavioral commitment, and communication. International Business Review, 25(1), 370-381.

Anderson, Rolph E., and Srini S. Srinivasan. 2003. E-satisfaction and e-loyalty: A contingency framework. Psychology and Marketing, 20: 123-38.

Ba, S. \& Paul A. Pavlou. 2002. Evidence of the Effect of Trust Building Technology in Electronic Markets: Price Premiums and Buyer Behavior. MIS Quarterly, 26(3), 243-268.

Badrinarayanan, V. and Laverie, D.A. 2011. Brand advocacy and sales effort by retail salespeople: antecedents and influence of identification with manufacturers' brands. Journal of Personal Selling and Sales Management, Vol. 31 No. 2, pp. 123-140.

Berrozpe, A., Campo, S., \& Yagüe, M. J. 2018. Am I lbiza? Measuring brand identification in the tourism context. Journal of Destination Marketing \& Management.

Ghozali, I. (2017). Model Persamaan Struktural Konsep dan Aplikasi dengan Program AMOS ver 24. Semarang: BP Universitas Diponegoro.

Griffin, Jill. (2005). CL: Menumbuhkan dan Mempertahankan Kesetiaan Pelanggan. Jakarta: Erlangga.

Hair, J. F. JR., Black, W.C., Babin, B. J., Anderson, R. E., Tatham, R. L.. 2010. Multivariate Data Analysis $7^{\text {th }}$ Edition. Boston: Pearson. 
Homburg, Christian, Danijel Jozic' and Christina Kuehnl. 2017. Customer Experience Management: Toward Implementing an Evolving Marketing Concept. Journal of the Academy of Marketing Science, 45, 377401.

Karjaluoto, H., Jayawardhena, C., Pihlstr€om, M., \& Lepp€aniemi, M.. 2015. Effects of service quality, trust, and perceived value on $\mathrm{CL}$ : The case of mobile subscribers. In Proceedings of the 2009 Academy of Marketing Science (AMS) Annual Conference, Baltimore, Maryland, p. 179.

Kotler, Philip, and Gary Amstrong. 2013. Principles of Marketing 15th Edition. USA: Pearson

Kotler, Philip, and Kevin Lane Keller. 2015. Marketing Management 15th Edition. USA: Pearson.

Lam, S.K., Ahearne, M., Mullins, R., Hayati, B. and Schillewaert, N. (2013), Exploring the dynamics of antecedents to consumer Brand identification with a new Brand. Journal of the Academy of Marketing Science, Vol. 41 No. 2, pp. 234-252.

Lin, Y. H.. 2015. Innovative brand experience's influence on brand equity and brand satisfaction. Journal of Business Research, 68(11), 2254-2259.

Nunally J.C, Bernstein, IH. 1994. Psysikometric Theory 3 rd Edition. NEW YORT, Mc: Graw-Hill.

Raouf Ahmad Rather, Linda D. Hollebeek. 2019. Exploring and validating social identification andsocial exchangebased drivers of hospitality CL. International Journal of Contemporary Hospitality Management.

Rosemary Matikiti, Mornay Roberts-Lombard \& Mercy Mpinganjira. 2019. Customer attributions of service failure and its impact on commitment in the airline industry: an emerging market perspective. Journal of Travel \& Tourism Marketing, 36:4, 403-414.

Sekaran, Uma and Roger Bougie. 2016. Research Methods for Business 7th Edition. United Kingdom: Wiley.

Zhen Shao, Yanning Guo, and Chaoyi Ge. 2019. Impact of Perceived Value on SAT and Continuance Intention of Bicycle Sharing Service. Proceedings of the 52nd Hawaii International Conference on System Sciences. 